\title{
Phytosociology and Floristic Composition of the Infesting Community in Rice Crop Waterlogged
}

\author{
Bruna Penha Costa ${ }^{*}$, Maria Rosangela Malheiros Silva², Carlos Augusto Rocha de Moraes Rego', \\ Juan López de Herrera ${ }^{3}$, Maria Soraia Fortado Vera Cruz ${ }^{1}$, Ana Carolina Pinguelli Ristau1, \\ Marinez Carpiski Sampaio', Thatiane Nepomuceno Alves ${ }^{1}$, Shirlene Souza Oliveira ${ }^{1}$, \\ Hannah Braz ${ }^{1}$, Nitalo Andre Farias Machado ${ }^{1}$
}

${ }^{1}$ Center of Agrarian Sciences, State University of Western Paraná, Marechal Cândido Rondon, Brazil

${ }^{2}$ Center of Agrarian Sciences, State University of Maranhão, São Luís, Brazil

${ }^{3}$ University School of Agricultural Technical Engineering, Polytechnic University of Madrid, Madrid, Spain

Email: ^bruna.penhacosta@hotmail.com

How to cite this paper: Costa, B.P., Silva, M.R.M., de Moraes Rego, C.A.R., de Herrera, J.L., Cruz, M.S.F.V., Ristau, A.C.P., Sampaio, M.C., Alves, T.N., Oliveira, S.S., Braz, H. and Machado, N.A.F. (2018) Phytosociology and Floristic Compositionof the Infesting Community in Rice Crop Waterlogged. American Journal of Plant Sciences, 9, 353-367.

https://doi.org/10.4236/ajps.2018.93028

Received: January 15, 2018

Accepted: February 9, 2018

Published: February 12, 2018

Copyright (c) 2018 by authors and Scientific Research Publishing Inc. This work is licensed under the Creative Commons Attribution International License (CC BY 4.0).

http://creativecommons.org/licenses/by/4.0/ c) (i) Open Access

\begin{abstract}
The objective of this study is to identify and quantify the floristic composition of the weed community in the rice crop waterlogged in the municipality of Arari-MA. The botanical material was obtained in three areas by randomly a hollow rectangle of $0.50 \mathrm{~m} \times 0.30 \mathrm{~m}$ by forty five times in each plot. The aerial parts of weeds were harvested, identified, counted and oven dried with forced air ventilation at $333.15 \mathrm{~K}$ to $343.15 \mathrm{~K}$. These data were used to determine the phytosociological parameters and the Shannon-Wiener diversity index was also calculated. A total of 6607 plants were collected, being $4115(62.28 \%)$ in the vegetative phase and $2492(37.72 \%)$ in the reproductive phase. The monocotyledonous group obtained the largest number of plants, 2882 in the vegetative phase and 1535 in the reproductive phase. The Cyperaceae family recorded nine species and four genera and the Poaceae, seven and four species in the vegetative and reproductive phases, respectively. The species of higher IVI in the vegetative phase was E. sellowiana in the area A1 with $82.86 \%$, and in the reproductive $F$. dichotoma with IVI of $90.49 \%$ in the area A3. The individuals density and species richness were higher in the vegetative phase of the culture and the monocotyledonous group predominated with the Cyperaceae and Poaceae families, and the weed diversity among the areas was low.
\end{abstract}

\section{Keywords}

Diversity, Oryza sativa L., Weeds 


\section{Introduction}

Rice (Oryza sativa L.) is one of the most important foods for human nutrition, being the food basis of billions of people and the second most cultivated cereal in the world, occupying an approximate area of 158 million hectares. The annual production is about 7467 million tons of grains in bark, which corresponds to $29 \%$ of the total grains used in human consumption [1]. In Brazil, rice cultivation occupies a prominent position in agribusiness, being the ninth largest rice producer and the largest among non-oriental countries [2].

According to the Brazilian Institute of Geography and Statistics [3] Brazil produced in the 2016/2017 harvest a total of 11,759,096 tons of rice. The northeast region of the country produced 487,697 tons, accounting for $4 \%$ of the total produced. The State of Maranhão was the largest producer of this cereal with $50.26 \%$.

The State of Maranhão is a recognized upland rice producer and has a potential of about 3.5 million hectares of irrigable land. The cultive has a great importance in the north central region of Maranhão that has about 2000 hectares of irrigated rice, mainly in the municipalities of Arari and São Mateus. In this microregion, there are associations of producers that use family labor in small plots with about 1.5 to 4.0 hectares in average [4].

One of the limiting factors for rice production in the north central region of Maranhão is the infestation of weed areas that compete with the crop for the resources needed to reach its cycle, which reduces the production of rice due to the removal of nutrients in the same plot. [5] reported that in the north central region of Maranhão, the presence of weeds during the whole crop cycle caused losses of $83.4 \%$ to $71.0 \%$ in production and the damage caused by weeds in rice crop was mainly due to the competition by water, light and nutrients of the soil, besides the difficulties or impediments to the harvest [6].

The technical knowledge, of which weeds are the most damaging to the crop, is of paramount importance for the control, as these can vary according to their competitive ability. This knowledge is usually carried out through the phytosociological indexes, of which the most used are relative density, relative frequency, relative dominance and importance value index. [7] points out that these indices contribute to infer the impact of management systems and agricultural practices on the dynamics of growth and occupation of weed communities in agroecosystems. While [8] emphasises that knowledge of the most important species allows us to decide the best management to be adopted, be it cultural, mechanical, physical, biological, chemical or integrated.

In addition to the contribution of the phytosociological indices to the knowledge of the species in a given area, there are also the diversity indexes that according to [9] allow the internal characterization of each area, providing additional support for researcher's inferences about a particular community. This diversity can be measured by the Margalef, Simpson or Shannon-Wiener indices. The analysis of these indices allows to evaluate the balance between plant spe- 
cies, that is, the "equilibrium" of the plants populations in the communities [10]. The Shannon-Wiener index is one of the most widely used in ecological studies of communities indicating the floristic diversity based on the natural logarithm, which considers equal weight among rare and abundant species, considering that the higher the value of this index, the greater the floristic diversity [11].

This work have as objective identify and quantify the floristic composition of the infesting community in rice culture in the municipality of Arari-MA, located in the north central region of state Maranhão.

\section{Materials and Methods}

The research was conducted during the rainy season from February to May 2015 in the municipality of Arari-MA in the lowland Maranhense, located in the north central region of Maranhão, between coordinates $03^{\circ} 27^{\prime} 38^{\prime \prime}$ south latitude and $44^{\circ} 46^{\prime} 56^{\prime \prime}$ west longitude. The dominant climate is AW type, according to Köppen's classification [12]. With an average annual temperature of more than $300.15 \mathrm{~K}$ and an annual average relative humidity of more than $82 \%$, annual precipitation reaches a total of between 1600 and $2000 \mathrm{~mm}$ [13]. In relation to the type of soils of the experimental areas, it is classified as typical Allelic Melancholic Gleissolo [14].

In order to collect the botanical material, we selected three areas of rice farmers, approximately of $1 \mathrm{ha}$, in flooded systems in the municipality of Arari-MA, with the following areas: area A1 located in Picarreira Village, area A2 in Muquira Village and area A3 in the Trizidela Village. In each area two collections were made, one in the vegetative phase and the other in the reproductive phase of the cultive.

The collection of botanical material in all areas was obtained by means of a $0.50 \mathrm{~m} \times 0.30 \mathrm{~m}$ mold rectangle randomly cast forty-five times in the rice crop at a distance of approximately $1 \mathrm{~m}$ between one launch and another, so as to obtain a broad sampling of the area. At each launch of the rectangle, the aerial parts of the weeds were harvested, packed in plastic bags for identification and counting of individuals by species.

Weed identification were performed through the examination of material and consultation of relevant literature. Afterwards, the plants were packed in paper bags and dried in an oven with air ventilation, at a temperature between $333.15 \mathrm{~K}$ and $343.15 \mathrm{~K}$, until reach a constant mass, then later weigh in a precision scale.

Density and dry mass of weeds were expressed in numbers of plants and grams of dry mass per square meter, respectively. These data for each population were used to determine phytosociological indices: density, relative density, frequency, relative frequency, relative dominance and importance value index, represented by the following formulas:

1) Relative Density [15]:

$$
\text { De.R }=\frac{\text { number of individuals of a species in the samplings }}{\text { total number of individuals sampled from the community }} \times 100(\%)
$$


Relative density is a percentage relation between the number of individuals of a species in relation to the total number of individuals in the weed community.

2) Frequency [16]:

$$
\mathrm{Fr}=\frac{\text { number of samples in which a determined species occurred }}{\text { total number of samples taken }} \times 100(\%)
$$

Frequency is expressed in terms of percentage of sample in which the individuals of a species were detected in relation to the total number of samples taken.

3) Relative Frequency [16]:

$$
\text { Fr.R }=\frac{\text { absolute frequency of a determined population }}{\text { sum of the frequencies of community populations }} \times 100(\%)
$$

The relative frequency refers to the percentage relation of the frequency of a population in relation to the sum of the frequencies of all the populations that make up the community.

4) Relative Dominance [16]:

$$
\text { Do. } \mathrm{R}=\frac{\text { dry mass accumulated by the population }}{\text { dry mass accumulated by the community }} \times 100(\%)
$$

The relative dominance of a population is the relationship between the dry mass accumulated by the species in relation to the total dry mass accumulated by the weed community. Several parameters can be used as dominance: frequency, density, basal area and others, but according to [17] in the case of weed communities, it is accepted that species with higher accumulations of dry matter influence to a greater degree the behavior of the species.

5) Importance Value Index [16]:

$$
\mathrm{IVI}=\text { De. } \mathrm{R}+\mathrm{Fr} . \mathrm{R}+\text { Do.R }
$$

Importance Value Index is the sum of the relative values of density, frequency and dominance of each species. It is an index that expresses an importance value of each species in the weed community.

In addition to the phytosociological indexes, the diversity index of Shannon-Wiener [18] was also calculated for each area during the cropping phases. This quantifies the species diversity of a system considering species richness and uniformity and was obtained by the formula:

$$
H^{\prime}=-\sum_{i=1}^{s} p i \ln p i
$$

where: $\ln$ is the logarithm Nigerian of; $p i=n i / N$; $n i$ is the number of individuals sampled from species $i ; N$ is the total number of individuals sampled.

The identifications of the botanical material were carried out in the Rosa Mochel Herbarium of the Nucleus of the State University of Maranhão in São Luís-MA, according to the usual techniques. The classification system adopted for families and species was the Angiosperm Phylogenetic Group III (APG III) [19]. The information obtained was tabulated through Microsoft Office Excel 2010 soft- 
ware.

\section{Results and Discussion}

In the three evaluated areas, a total of 6607 individuals were collected; in the vegetative phase of the rice crop there were $4115(62.28 \%)$ and in the reproductive phase $2492(37.72 \%)$. Among the samples collected in the vegetative phase, 2882 belonged to the monocotyledonous botanical group and 1233 of the dicotyledonous. In the reproductive phase, we obtained 1535 plants of the monocotyledonous group and 957 of the dicotyledonous group (Figure 1). It can be inferred that the interference of the weed community was higher in the vegetative phase than in the reproductive phase with a high density of the botanical group of monocotyledonous.

Research by [20] on upland rice cultivation also showed similar results with the majority of individuals occurring in the vegetative phase and belonging to the monocotyledonous botanical group. [17] and [21] point out that generally the closer to the morphological and physiological of two species, the more similar their demands will be on growth factors, and the more intense competition will be for the limited resources in the common environment.

In the vegetative phase of the crop, area A2 presented the largest number of individuals with 1791, followed by area A1 with 1340 and A3 with 984 individuals. In the reproductive phase, the area $\mathrm{A} 1$ that registered the highest density of individuals (1147), since areas A3 and A2 presented 724 and 621 individuals, respectively (Figure 1). The high density of individuals in the area $\mathrm{A} 1$ reproductive phase suggests that weed control in the vegetative stage was probably not efficient.

A total of 42 species and 34 genera were identified in 17 families, of which 36 species and 16 families occurred in the vegetative phase of the crop; while in the reproductive phase, there were 18 species and 10 families (Table 1 and Table 2). This evidences that the number of species and families was higher in the vegetative phase and that the rice cultivated in the humid tropics in low areas subject to flooding presents high diversity of species. These results corroborate the

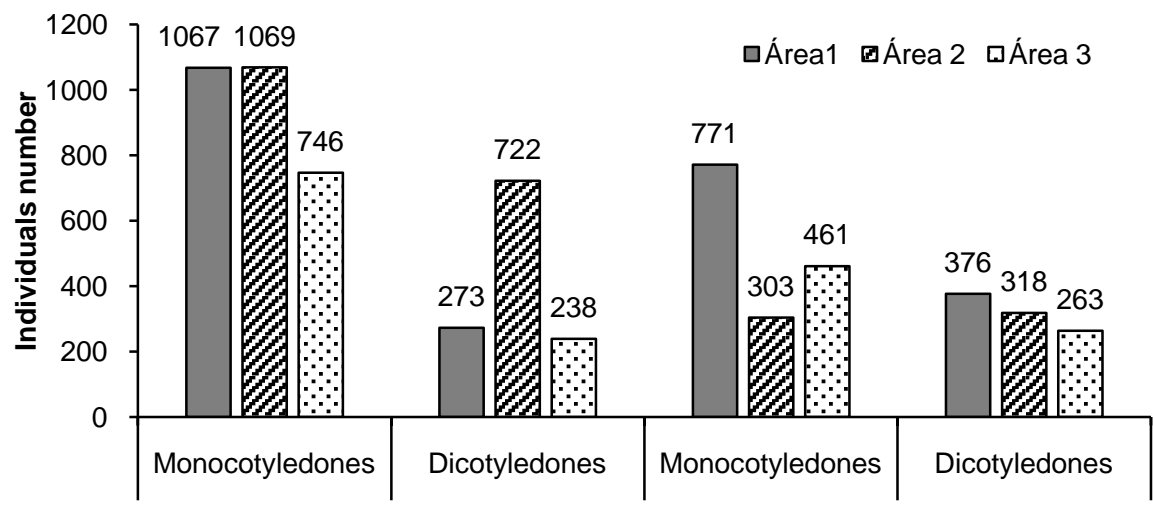

Figure 1. Number of weed individuals per botanical group collected in the vegetative and reproductive phases of the rice crop in the municipality of Arari-MA, 2015. 
Table 1 . Weed family and species identified in the vegetative phase of rice crop in three areas of the municipality of Arari-MA, 2015.

\begin{tabular}{|c|c|c|c|c|}
\hline \multirow{2}{*}{ Family } & \multirow{2}{*}{ Species } & \multicolumn{3}{|c|}{ Areas } \\
\hline & & $\mathrm{A} 1$ & A2 & $\mathrm{A} 3$ \\
\hline Aizoaceae & Unknown & $\mathrm{X}$ & ------- & $\cdots$ \\
\hline \multirow{2}{*}{ Asteraceae } & Eclipta alba (L.) Hassk. & ------ & $\mathrm{X}$ & $-\cdots--\cdot$ \\
\hline & Centratherum punctatum Cass. & $\mathrm{X}$ & $\mathrm{X}$ & $\mathrm{X}$ \\
\hline \multirow{3}{*}{ Commelinaceae } & Commelina benghalensis $\mathrm{L}$. & ------ & $\mathrm{X}$ & $-\cdots--\cdot$ \\
\hline & Murdannia nudiflora (L.) Brenan & $\mathrm{x}$ & $\mathrm{X}$ & $\mathrm{X}$ \\
\hline & Ipomoea purpurea (L.) Roth. & ------ & ------ & $\mathrm{X}$ \\
\hline \multirow[t]{6}{*}{ Convolvulaceae } & Ipomoea sp & $\mathrm{x}$ & ------ & $\mathrm{X}$ \\
\hline & Unknown & ------ & ------ & $\mathrm{X}$ \\
\hline & Bulbostylis capillaris (L.) C. B. Clarke & $\mathrm{X}$ & $\mathrm{X}$ & $\mathrm{X}$ \\
\hline & Eleocharis sellowiana Kunth & $\mathrm{x}$ & ------ & $-\cdots--\cdot$ \\
\hline & Cyperus articulatus $\mathrm{L}$. & $\mathrm{X}$ & $\mathrm{X}$ & $\mathrm{X}$ \\
\hline & Cyperus esculentus $\mathrm{L}$. & ------ & $\mathrm{X}$ & $-\cdots--\cdot$ \\
\hline \multirow{6}{*}{ Cyperaceae } & Cyperus hermaphroditus (Jacq.) Stand. & $\mathrm{X}$ & $\mathrm{X}$ & $\mathrm{X}$ \\
\hline & Cyperus rotundus $\mathrm{L}$ & ------ & $\mathrm{X}$ & $----\cdot$ \\
\hline & Cyperus sp. & $\mathrm{X}$ & $\mathrm{X}$ & $\mathrm{X}$ \\
\hline & Fimbristylis dichotoma (L.) Vahl. & $\mathrm{X}$ & $\mathrm{X}$ & $\mathrm{X}$ \\
\hline & Rhynchospora nervosa (Vahl.) Boeck & $---\cdot--$ & $\mathrm{X}$ & $-\cdots-\cdot$ \\
\hline & Scleria melaleuca Rchb. & ------ & $\mathrm{X}$ & $---\cdot$ \\
\hline \multirow[t]{3}{*}{ Euphorbiaceae } & Chamaesyce hyssopifolia (L.) Small & $\mathrm{X}$ & $\mathrm{X}$ & $\mathrm{X}$ \\
\hline & Aeschynomene denticulata Rudd. & $\mathrm{X}$ & $\mathrm{X}$ & $\mathrm{X}$ \\
\hline & Aeschynomene rudis Benth. & $\mathrm{x}$ & $\mathrm{X}$ & $\mathrm{X}$ \\
\hline \multirow{4}{*}{ Fabaceae } & Calopogonio mucunoides Desv. & ------ & $\mathrm{X}$ & --- \\
\hline & Chamaecrista rotundifolia (Pers.) Greene & $\mathrm{X}$ & $\mathrm{X}$ & $\mathrm{X}$ \\
\hline & Crotalaria retusa L. & ------ & ------- & $\mathrm{X}$ \\
\hline & Mimosa pudica L. & $\mathrm{x}$ & ------ & $-\cdots$ \\
\hline Loganiaceae & Spigelia anthelmia L. & $\mathrm{X}$ & $\mathrm{X}$ & $\mathrm{X}$ \\
\hline \multirow{2}{*}{ Malvaceae } & Malachra fasciata Jacq. & $\mathrm{X}$ & $\mathrm{X}$ & $\mathrm{X}$ \\
\hline & Pavoniasp & ------ & $\mathrm{X}$ & --- \\
\hline \multirow{2}{*}{ Onagraceae } & Ludwigia sp. & $\mathrm{x}$ & ------ & $\mathrm{X}$ \\
\hline & Ludwigia octovalvis (Jacq). Raven & $\mathrm{x}$ & $\mathrm{X}$ & $----\cdot-$ \\
\hline Phyllantaceae & Phyllanthus tenellus Roxb. & ------ & ------ & $\mathrm{X}$ \\
\hline Plantaginaceae & Lindernia crustaceae $\mathrm{L}$. & $\mathrm{x}$ & ------ & $----\cdot-$ \\
\hline \multirow{9}{*}{ Poaceae } & Urochloa platyphylla (Griseb.) Nash & $\mathrm{X}$ & ------ & $\mathrm{X}$ \\
\hline & Urochloasp. & $\mathrm{X}$ & ------- & $\mathrm{X}$ \\
\hline & Cynodon dactylon (L.) Pers. & $\mathrm{X}$ & ------ & $\mathrm{X}$ \\
\hline & Digitaria sp. & $\mathrm{x}$ & $\mathrm{X}$ & $\mathrm{X}$ \\
\hline & Echinochloa colonum (L.) Link. & $\mathrm{X}$ & $\mathrm{X}$ & $\mathrm{X}$ \\
\hline & Eleusine indica (L.) Gaert. & $\mathrm{x}$ & $\mathrm{X}$ & $\mathrm{x}$ \\
\hline & Panicum maximum Jacq. & $\mathrm{x}$ & ------ & $\mathrm{X}$ \\
\hline & Paspalum maritimun Trin. & ------ & $\mathrm{X}$ & $-\cdots$ \\
\hline & Urochloa mutica L. & $\mathrm{X}$ & ------ & $\mathrm{X}$ \\
\hline \multirow[t]{2}{*}{ Portulacaceae } & Unknown & $\mathrm{x}$ & ------ & $-\cdots--\cdot$ \\
\hline & Hedyotis corymbosa (L.) F. Muell & ------ & $\mathrm{X}$ & $-\cdots-\cdot-$ \\
\hline \multirow[t]{2}{*}{ Rubiaceae } & Spermacoce sp. & $\mathrm{X}$ & $\mathrm{X}$ & $\mathrm{X}$ \\
\hline & Spermacoce capitata Ruiz \& Pav. & $\mathrm{X}$ & $\mathrm{X}$ & $\mathrm{X}$ \\
\hline \multirow{2}{*}{ Solanaceae } & Physalis angulata $\mathrm{L}$. & $\mathrm{X}$ & $\mathrm{X}$ & $\mathrm{X}$ \\
\hline & Solanum sp. & $\mathrm{X}$ & $\mathrm{X}$ & $-\cdots--\cdot$ \\
\hline
\end{tabular}


Table 2. Weed family and species identified in the reproductive phase of rice cultivation in three areas of the municipality of Arari-MA, 2015.

\begin{tabular}{|c|c|c|c|c|}
\hline \multirow{2}{*}{ Family } & \multirow{2}{*}{ Species } & \multicolumn{3}{|c|}{ Areas } \\
\hline & & $\mathrm{A} 1$ & A2 & A3 \\
\hline \multirow[t]{3}{*}{ Asteraceae } & Eclipta alba (L.) Hassk. & ------ & $\mathrm{X}$ & $\mathrm{X}$ \\
\hline & Bulbostylis capillaris (L.) C. B. Clarke & $\mathrm{X}$ & $\mathrm{X}$ & $\mathrm{X}$ \\
\hline & Cyperus hermaphroditus (Jacq.) Stand. & $---\cdot--$ & $\mathrm{X}$ & $\mathrm{X}$ \\
\hline \multirow[t]{3}{*}{ Cyperaceae } & Cyperus sp. & $\mathrm{X}$ & $\mathrm{X}$ & $\mathrm{X}$ \\
\hline & Fimbristylis dichotoma (L.) Vahl. & $\mathrm{X}$ & $\mathrm{X}$ & $\mathrm{X}$ \\
\hline & Scleria melaleuca Rchb. & $\mathrm{X}$ & ------ & $\mathrm{X}$ \\
\hline \multirow{2}{*}{ Euphorbiaceae } & Chamaesyce hyssopifolia (L.) Small & $\mathrm{X}$ & $\mathrm{X}$ & $\mathrm{X}$ \\
\hline & Caperonia palustris (L.) St. Hil. & $\mathrm{X}$ & $\mathrm{X}$ & $\mathrm{X}$ \\
\hline \multirow{4}{*}{ Fabaceae } & Aeschynomene denticulata Rudd. & $\mathrm{X}$ & ------ & $\mathrm{X}$ \\
\hline & Chamaecrista rotundifolia (Pers.) Greene & ------ & $\mathrm{X}$ & ------- \\
\hline & Senna obtusifolia (L.) Irwin \& Barneby & $\mathrm{X}$ & $\mathrm{X}$ & $\mathrm{X}$ \\
\hline & Vigna longifolia L & $\mathrm{X}$ & $\mathrm{X}$ & $\mathrm{X}$ \\
\hline \multirow{2}{*}{ Malvaceae } & Malachra fasciata Jacq. & $\mathrm{X}$ & $\mathrm{X}$ & $\mathrm{X}$ \\
\hline & Corchorus argutus $\mathrm{L}$. & $\mathrm{X}$ & $\mathrm{X}$ & $\mathrm{X}$ \\
\hline Musaceae & Musa sp. & ------ & ------ & $\mathrm{X}$ \\
\hline Onograceae & Ludwigia octavalvis (Jacq). Raven & $\mathrm{X}$ & $\mathrm{X}$ & $\mathrm{X}$ \\
\hline \multirow{2}{*}{ Phyllantaceae } & Phyllanthus niruri L. & ------ & ------- & $\mathrm{X}$ \\
\hline & Phyllanthus tenellus Roxb. & $\mathrm{X}$ & $\mathrm{X}$ & $\mathrm{X}$ \\
\hline \multirow{4}{*}{ Poaceae } & Urochoa sp & ----- & ----- & $\mathrm{X}$ \\
\hline & Cynodon dactylon (L.) Pers. & $\mathrm{X}$ & ------- & ------ \\
\hline & Digitaria sp. & $\mathrm{X}$ & $\mathrm{X}$ & $\mathrm{X}$ \\
\hline & Panicum sp & $\mathrm{X}$ & ------ & $-\cdots--$ \\
\hline Rubiaceae & Spermacoce capitata Ruiz \& Pav. & $\mathrm{X}$ & ------ & ------- \\
\hline
\end{tabular}

findings of [22] in the northern Maranhense mesoregion in two crops of rice, 52 species distributed in 18 families in the first crops and second, 37 species and 17 families. High species richness was also verified by [23] in Colombia who obtained 42 species grouped in 20 families and 31 genera.

The families Cyperaceae and Poaceae contributed the largest number of weed species in the areas. In the vegetative phase, the family Cyperaceae recorded nine and the Poaceae, seven species and in the reproductive one were four species and four genera for the families Cyperaceae and Poaceae, respectively (Table 1 and Table 2). These families were very diverse and representative of weeds in the evaluated areas, with species very competitive with the rice crop. Similar results were obtained by [5] in the northern mesoregion of Maranhão that identified 10 species of Cyperaceae and 12 species of Poaceae in the first crop and in Colom- 
bia by [23] that verified thirteen species of Poaceae and six species of Cyperaceae.

In the family Cyperaceae it was observed that Cyperus sp and Fimbristylis dichotoma were common in all areas in the two phases evaluated of the cultive and for family Poaceae was the genus Digitaria sp. In addition to this genus of the family Poaceae were also relevant Eleusine colonum and Eleusine indica in the vegetative phase in all areas (Table 1 and Table 2). These species are important weeds of rice crop and the frequency in the two phases evaluated in all the areas suggests a great adaptation to the local conditions that can be consequence of the use of the same type of management. According to [24], the use of the same cropping system in a given area for several consecutive years can increase the selection pressure under the weed communities, selecting the species most adapted to the crop system, as well as favoring the emergence of plants resistant to herbicides.

The species of the genus Cyperus and Fimbristylis of the Cyperaceae family are among the most important and harmful weeds in rice cultivation. [24] in rice area without rotation observed among the species of greater relative importance, Fimbristylis miliaceae and Cyperus iria. [25] in a study of floristic characterization of the weed seed bank upland rice cultivation also verified the genus Cyperus and Fimbristylis among those of higher incidence in the family Cyperaceae. [5] in a study of weed interference in rice crop identified species of the highest relative importance during the whole period of coexistence, species of the genus Cyperus with 35.22\% in the agricultural year 2010/2011 and [26] in Nepal also obtained among the most dominant species under conditions of direct sowing and transplanting of rice, species of the genus Cyperus and Fimbristylis.

Species of the family Poaceae Digitaria sp, E. columum and E. indica are among the most important weeds of the rice plantations due to the high levels of infestation and control difficulties of several producing regions. Research in Pakistan by [27] reported E. colonum as the most competitive weed in rice cultivation causing losses of $56 \%$ at $42 \%$ in yield. [28] in Malaysia verified in two seasons, the dominance of $E$. indica followed by a species of the genus Digitaria in the rice plots. [20] cited E. indica as a species of high importance in the seed bank of rice areas in state of Maranhão, in Brazil. Considering the high losses that the species of the families Cyperaceae and Poaceae provoke in the cultivation of the rice, it is necessary to establish the management for these families, in order to avoid high economic losses to the farmers.

Another relevant family in the study was the Fabaceae of the group of dicotyledonous that presented six species in the vegetative phase and four species in the reproductive. Among the species in all areas were Aeschynomene denticulata, Aeschynomene rudis and Chamaecrista rotundifolia in the vegetative and reproductive phases, Senna obtusifolia and Vigna longifolia (Table 1 and Table 2). Between the species identified, the genus Aeschynomene stands out with high importance in irrigated rice crops in Rio Grande do Sul. Studies conducted by 
[29] in this State verified competition between two rice cultivars and $A$. denticulata that reduced the tillering or number of composite leaves, the height of plants, the leaf area and the dry mass of the cultivars used.

The analysis of the importance value index in the vegetative phase of the rice crop for all areas shows that the species of higher IVI was Eleocharis sellowiana in the A1 area with $82.86 \%$ and that the relative dominance $(76.08 \%)$ was the component of greatest contribution to its importance (Figure 2). The high relevance of E. sellowiana in the weed community due to the accumulation of biomass, but the low population density and frequency, making the control of this species more localized in the area. According to [30], this species belongs to the family Cyperaceae, is an annual, cespitosa plant, reproduced by seeds that under optimal conditions of luminosity and water resources proliferates, occurring in poorly drained soils.

Following the species with the highest importance value index (IVI) in the vegetative phase, C. rotundifolia (69.09\%) and F. dichotoma (53.14\%) were highlighted in the A2 area. These species had the most influential IVI parameters, relative dominance $(50.55 \%)$ and relative density $(33.72 \%)$, respectively (Figure 2). The species $C$. rotundifolia is characterized by being an herbaceous perennial plant, native to Brazil, common on grasslands and road sides, too occurring in pasture areas [31]. Studies in Bahia conducted by [32] showed this species as the fifth most important species in the cassava crop, and [33] indicated they are the fourth in grasses sown with Paspalum notatum.

For $F$. dichotoma whose relative density was the main parameter of IVI influence, the results are in agreement with those obtained by [34] in Vigna unguiculata in a shriveled capoeira system in which the relative density of this species was $38 \%$ at 30 days after sowing. This high density was attributed to the evaluation method that considers each tiller as an individual in the score. This genus was also identified in a phytosociological survey conducted by [5] in state of Maranhão in upland rice culture and by [24] in the cultivation of irrigated rice

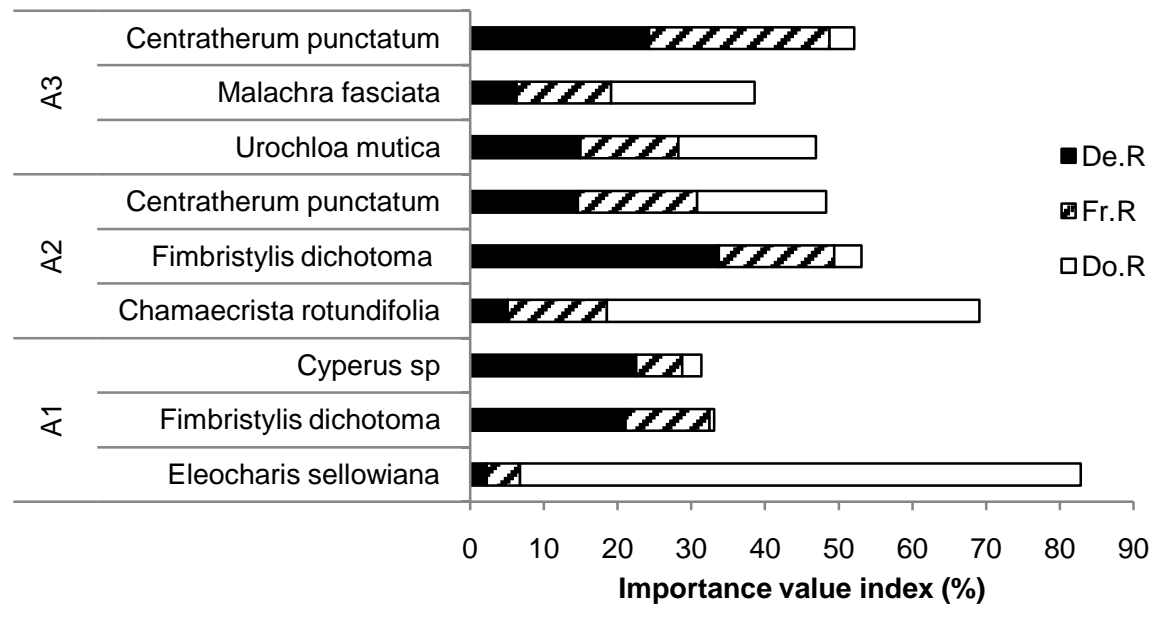

Figure 2. Phytosociological parameters of the main weeds in the vegetative phase of the rice crop in three areas of the municipality of Arari-MA, 2015. 
without rotation in which the species of this genus obtained the highest relative importance in $84.46 \%$ due to the high relative density in $38.8 \%$.

In the A3 area, the species Urochloa mutica, Malachra fasciataand Centratherum punctatum recorded IVI of $38.68 \%, 38.60 \%$ and $37.09 \%$, respectively. The phytosociological parameters contributing to the index of importance of these species has a relative dominance for $U$. mutica $(18.61 \%)$ and $M$. fasciata (19.48\%) and for $C$. punctatum, relative density in $24.29 \%$, and the relative frequency in $24.44 \%$ (Figure 2). The differences between the IVIs of these species were not significant, suggesting a better balance between the species that compose the weed community in the A3 area and that the relative dominance, that is, the accumulation of biomass by $U$. mutica and $M$. fasciata was the determinant parameter in high degree on the behavior of these species.

In a study conducted by [35], Urochloa mutica is a forage adapted and used in degraded meadows and pastures, being a perennial, stoloniferous grass, but not very resistant to drought, and can greatly reduce its production when faced with drought. Whereas, [30] identified this genus as important invaders of the rice culture flooded by flood and, mainly, irrigation and drainage channels.

[24] in the area of rice crop rotation, rice/soybean for more than five years also verified among the present species, Malachra fasciata. According to [36], it is an annual sub shrub to shrub species that develops in the northern and northeastern regions of Brazil, vegetating in humid environments, such as swampy areas, flood areas and watercourses, where it becomes undesirable because of the injuries it causes.

In the studied areas, there was a change in the population dynamics of the weed community in the reproductive phase in comparison to vegetative, whose species of highest importance in all areas was $F$. dichotoma with an IVI of $77.64 \%$ in the area $\mathrm{A} 1,37.92 \%$ in the area $\mathrm{A} 2$ and $90.49 \%$ in the area $\mathrm{A} 3$. The importance level of this species was mainly influenced by the relative density, which was $36.44 \%$ in the area $\mathrm{A} 1,18.52 \%$ in the area $\mathrm{A} 2$ and $51.10 \%$ in the area $\mathrm{A} 3$ (Figure 3). The numerical density of this species shows the level of adaptation to the ecological conditions and the potential to compete with the crop in the reproductive phase in these areas. According to [30], this species is characterized by annual or perennial, depending on environmental conditions, with rapid growth, developing in both wet soil and drier soil, so its occurrence is not limited to the area of meadows.

In a study of seed bank in upland rice culture in the Alto Alegre do Pindaré city in the region of the Pre-Amazonia, this species also predominated in the reproductive phase with IVI of $37.90 \%$. [24] also verified the occurrence of this genus in the cultivation of irrigated rice without and with rotation with soybean in which F. miliaceae obtained the highest relative importance in the first system (84.46\%).

Other relevant IVI species in the reproductive phase were $S$. obtusifolia in areas A3 (39.44\%) and A2 (29.38\%), followed by Bulbostylis capillaris in the area A2 (44\%) and Corchorus argutus in the area A3 (29.47\%). For S. obtusifolia, 


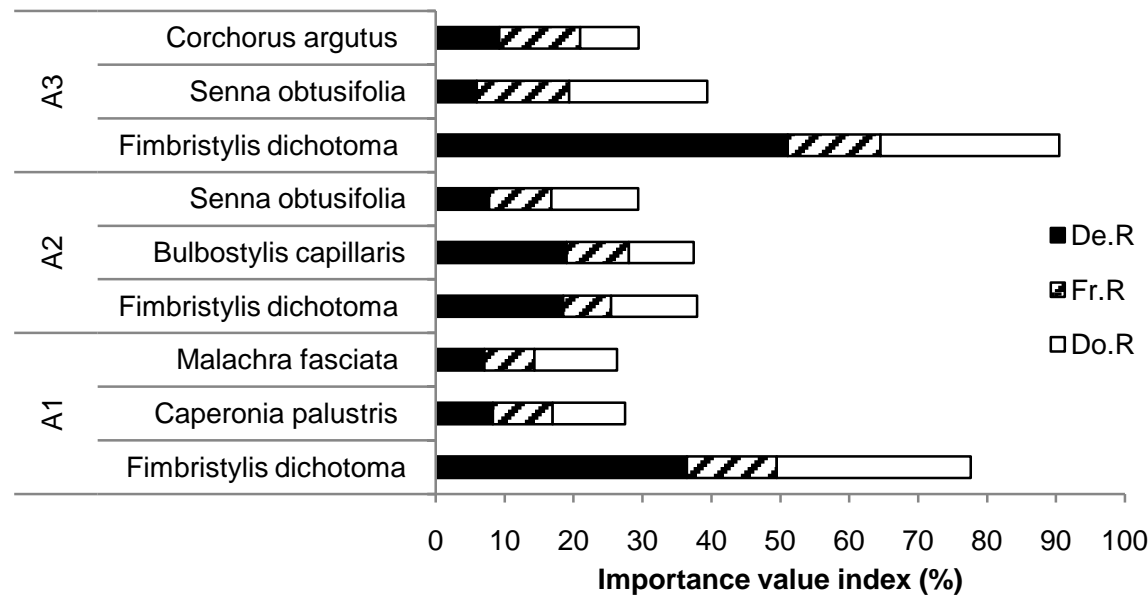

Figure 3. Phytosociological parameters of the main weeds in the reproductive phase of the rice crop in three areas of the municipality of Arari-MA, 2015.

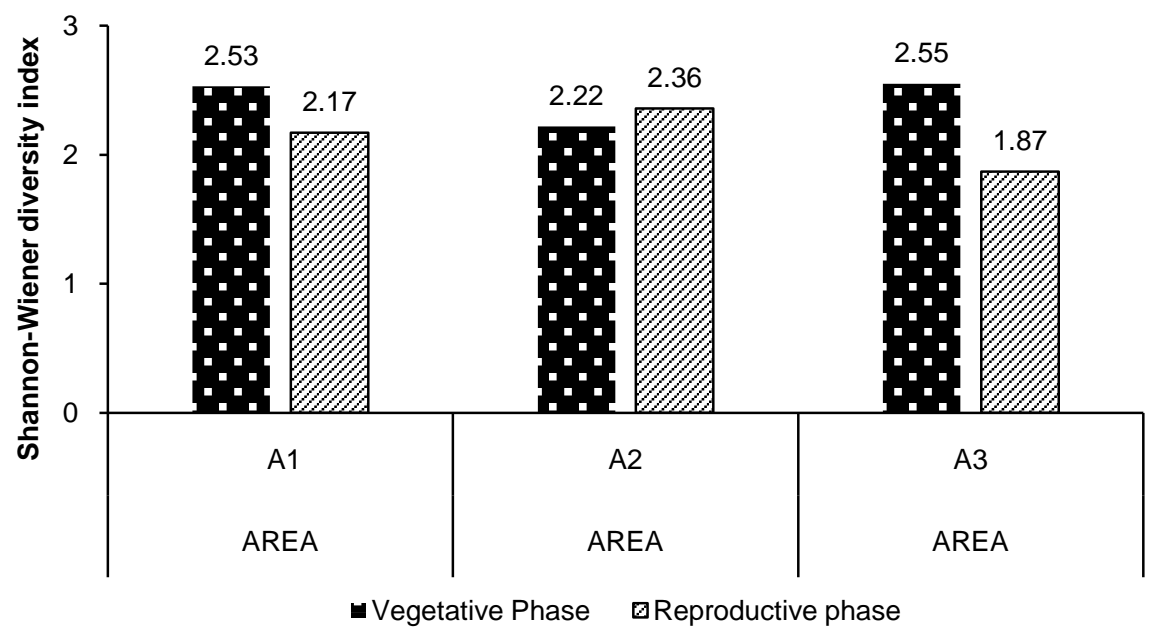

Figure 4. Shannon-Wiener $\left(\mathrm{H}^{\prime}\right)$ diversity index in the vegetative and reproductive phases of rice cultivation in three areas of the municipality of Arari-MA, 2015.

relative dominance was the main contributor of IVI in the two areas with values of $20.05 \%$ and $12.69 \%$ for areas A3 and A2, respectively. While for B. capillaris the relative density was $19 \%$ and $C$. argutus the relative frequency was $11.69 \%$ (Figure 3). These species were not expressive in the weed community in the vegetative phase of the crop in the evaluated areas indicating a change in the dynamics of the dominant species. Research by [23], showed that relative density was a determinant parameter for $S$. obtusifolia, but the results of this study showed that the relative dominance that influenced to a greater degree the behavior of this species. According to [36], it is an annual subarctic species that develops spontaneously throughout the country, occupying areas under cultivation, pastures, vacant lots and borders of forest fragments. Research conducted by [37] informed that this species shows lower initial growth rate, which may characterize it as a late weed.

In the evaluation of the diversity index of Shannon-Wiener $\left(\mathrm{H}^{\prime}\right)$ in the three 
areas there was variation between the vegetative and reproductive phases of the crop with values between 1.87 and 2.55. In the A1 area, there was a slight reduction in the diversity of weeds in the reproductive phase $\left(\mathrm{H}^{\prime}=2.17\right)$, while for area $\mathrm{A} 2$ a small increase occurred in this phase $\left(\mathrm{H}^{\prime}=2.36\right)$. However, it was the A3 area that presented the greatest diversity reduction in the reproductive phase $\left(\mathrm{H}^{\prime}=1.87\right)$ (Figure 4). It can be verified that the weed diversity in the researched areas was low, which is related to the agricultural practices in use that simplify the natural environments. Seed bank studies in rice cultivation conducted by [20] in the Pré-Amazônia in the state of Maranhão also obtained variation between the vegetative and reproductive phases of the crop with values from 2.07 to 2.45. [23] in phytosociological studies on rice cultivation in Colombia also found low diversity in the studied areas with the highest value of 2.7.

\section{Conclusions}

The density and weed species richness were higher in the vegetative than in the reproductive phase of the rice crop, and the monocotyledonous botanical group predominated in the two phases with the families Cyperaceae and Poaceae presenting the main weed species in the municipality of Arari-MA.

The most important species in the vegetative phase of rice cultivation for all areas was E. sellowiana and in the $\mathrm{A} 1$ area is the highest relative dominance. Other species in order of importance in the vegetative phase observed were: $C$. rotundifolia and $F$. dichotoma in the area A2 and $U$. mutica, $M$. fasciata and $C$. punctatum in the area $\mathrm{A} 3$. In the reproductive phase there was a change in the importance of the species in the weed community with $F$. dichotoma with higher IVI in all areas due to the high relative density. Other relevant species in the reproductive phase were $S$. obtusifolia in the areas A3 and A2, followed by $B$. capillaris in the area A2 and $C$. argutus in the area A3.

The weed diversity among the areas was low indicating that the agricultural practices in use are selecting these species in the municipality.

\section{Acknowledgements}

We want to give thanks to the Coordination for the Improvement of Higher Education Personnel (CAPES) by the scholarship of the master's degree and resources for conducting the research. To FAPEMA, for the granting of a scientific initiation grant and financial support to the Research Project on the Diversity and Ecology of Arthropods, Pathogens and Spontaneous Herbs in the Rice Culture in the State of Maranhão and the farmers who areas for research.

\section{References}

[1] Sociedade Sul-Brasileira de Arroz Irrigado (SOSBAI) (2016) Arroz irrigado: recomendações técnicas da pesquisa para o Sul do Brasil/Sociedade Sul-Brasileira de Arroz Irrigado. SOSBAI, Pelotas, RS, 200 p.

[2] United States Department of Agriculture (USDA) (2017) Rice Outlook. Economic 
Research Service.

https://www.ers.usda.gov/webdocs/publications/84727/rcs-17h.pdf?v=42961

[3] Instituto Brasileiro de Geografia e Estatistica (IBGE) (2017) Pesquisa mensal de previsão e acompanhamento das safras agrícolas no ano civil. Levantamento Sistemático da Produção Agrícola. Rio de Janeiro, 30, 1-83.

[4] Méndez Del Villar, P., Ducos, A., Ferreira, N.L.S., Pereira, J.A. and Yokoyama, L.P. (2001) Cadeia produtiva do arroz no Estado do Maranhão. Embrapa Meio-Norte, Teresina, $136 \mathrm{p}$.

[5] Silva, M.R.M., Cantanhede, J.D., Correa, M.J.P. and Mesquita, M.L.R. (2015) Phytosociology and Interference of Weeds in Upland Rice in Maranhão State, Northeastern Brazil. African Journal of Agricultural Research, 10, 3412-3420. https://doi.org/10.5897/AJAR2015.9916

[6] Silva, M.R.M. and Durigan, J.C. (2009) Períodos de interferência das plantas daninhas na cultura do arroz de terras altas II-cultivar Caiapó. Bragantia, 68, 373-379. https://doi.org/10.1590/S0006-87052009000200011

[7] Marques, L.J.P., Silva, M.R.M., Lopes, G.S., Corrêa, M.J.P., Araujo, M.S., Costa, E.A. and Muniz, F.H. (2011) Dinâmica de populações e fitossociologia de plantas daninhas no cultivo do feijão-caupi e mandioca no sistema corte e queima com o uso de arado. Planta Daninha, 29, 981-989.

https://doi.org/10.1590/S0100-83582011000500004

[8] Oliveira, A.R. and Freitas, S.P. (2008) Levantamento fitossociológico de plantas daninhas em áreas de produção de cana-de-açúcar. Planta Daninha, 26, 33-46. https://doi.org/10.1590/S0100-83582008000100004

[9] Concenço, G., Tomazi, M., Correia, I.V.T., Santos, S.A. and Galon, L. (2013) Phytosociological Surveys: Tools for Weed Science? Planta Daninha, 31, 469-482. https://doi.org/10.1590/S0100-83582013000200025

[10] Blanco, F.M.G. (2014). Classificação e Mecanismos de Sobrevivência das Plantas Daninhas. In: Monquero, P.A., Ed., RiMA, Aspectos da biologia e manejo das plantas daninhas, Rima, São Carlos, 33-60.

[11] Shannon, C.E. and Weaver, W. (1949) The Mathematical Theory of Communication. University of Illinois Press, Urbana, IL, 117 p.

[12] Köppen, W. (1948) Climatologia: con un estudio de los climas de la tierra. Fondo de Cultura Econômica, México, 479 p.

[13] SECRETARIA DO ESTADO DO PLANEJAMENTO E ORÇAMENTO (SEPLAN) (2013) Atlas do Maranhão. Nucleo Geoambiental-UEMA. SEPLAN, São Luis, 90 p.

[14] Santos, H.G., et al. (2014) Sistema Brasileiro de Classificação de Solos. 4th Edition, Embrapa Solos, Rio de Janeiro, 353 p.

[15] Curtis, J.T. and McIntosh, R.P. (1950) The Interrelations of Certain Analytic and Synthetic Phytosociological Characters. Ecology, 31, 434-435. https://doi.org/10.2307/1931497

[16] Mueller-Dombois, E. and Ellenberg, H. (1974) Aims and Methods of Vegetation ecology. John Wiley \& Sons, New York, 547 p.

[17] Pitelli, R.A. (2000) Estudos fitossociológicos em comunidades infestantes de agroecossistemas. Jornal Conserb, 1, 1-7.

[18] Magurran, A.E. (1988) Ecological diversity and its measurement. Princeton University Press, Princeton, NJ, 179 p. https://doi.org/10.1007/978-94-015-7358-0

[19] APG III (2009) An update of the Angiosperm Phylogeny Group Classification for the Orders and Families of Flowering Plants: APG III. Botanical Journal of the Lin- 
nean Society, 161, 105-121. https://doi.org/10.1111/j.1095-8339.2009.00996.x

[20] Silva, M.R.M., Costa, E.A., Marques, L.J.P. and Correa, M.J.P. (2014) Banco de sementes de plantas daninhas em áreas de cultivo de arroz de sequeiro na Pré-Amazônia Maranhense. Revista de Ciências Agrárias, 57, 351-357. https://doi.org/10.4322/rca.1297

[21] Pitelli, R.A. and Pitelli, R.L.C.M. (2004) Biologia e ecofisiologia das plantas daninhas. In: Vargas, L. and Roman, E.S., Eds., Manual de Manejo e Controle das Plantas Daninhas, Embrapa Uva e Vinho, Bento Gonçalves, 29-55.

[22] Silva, M.R.M. and Mendonza, R.A.M. (2000) Crescimento de Ischaemum rugosum Salisb. sob três níveis de sombreamento. Planta Daninha, 18, 187-198. https://doi.org/10.1590/S0100-83582000000200001

[23] Ramírez, S., Hoyos, C. and Plaza, T. (2015) Fitosociología de malezas asociadas al cultivo de arroz en el departamento del Tolima, Colombia. Agronomia Colombiana, 33, 64-73.

[24] Erasmo, E.A.L., Pinheiro, L.L.A. and Costa, N.V. (2004) Levantamento fitossociológico das comunidades de plantas infestantes em áreas de produção de arroz irrigado cultivado sob diferentes sistemas de manejo. Planta Daninha, 22, 195-201. https://doi.org/10.1590/S0100-83582004000200004

[25] Silva, M.R.M., Campos, D.R., Souza, R.L. and Corrêa, M.J.P. (2013) Cadastramento fitossociológico de plantas daninhas na cultura do arroz de terras altas. Revista de Ciências Agro-Ambientais, 11, 51-60.

[26] Paudel, B., Shrestha, A., Amgain, L.P. and Neupane, M.P. (2017) Weed Dynamics in Various Cultivars of Rice (Oryza sativa L.) under Direct Seeding and Transplanting Conditions in Lamjung. International Journal of Applied Sciences and Biotechnology, 5, 159-167. https://doi.org/10.3126/ijasbt.v5i2.17611

[27] Rabbani, N., Bajwa, R. and Javaid, A. (2011) Interference of Five Problematic Weed Species with Rice Growth and Yield. African Journal of Biotechnology, 10, 1854-1862.

[28] Suria, A.S.M.J., Juraimi, A.S., Rahman, M., Man, B.A. and Selamat, A. (2011) Efficacy and Economics of Different Herbicides in Aerobic Rice System. African Journal of Biotechnology, 10, 8007-8022. https://doi.org/10.5897/AJB11.433

[29] Galon, L., Guimarães, S., Radunz, A.L., de Lima, A.M., Burg, G.M., Zandoná, R.R., Bastiani, M.O., Belarmino, J.G. and Perin, G.F. (2015) Relative Competitiveness of Irrigated Rice Cultivars and Aeschynomene denticulata. Bragantia, 74, 67-74. https://doi.org/10.1590/1678-4499.0147

[30] Kismann, K.G. and Groth, D. (1997) Plantas infestantes e nocivas. 2nd Edition, BASF, São Paulo, 978 p.

[31] Lorenzi, H. (2008) Plantas Daninhas do Brasil: Terrestres, Aquáticas, Parasitas e Tóxicas. 4th Edition, Instituto Plantarum, Nova Odessa, 640 p.

[32] Cardoso, A.D., Viana, A.E.S., Barbosa, R.P., Teixeira, P.R.G., Cardoso Júnior, N.S. and Fogaça, J.J.N.L. (2013) Phytosociological Survey of Weeds in Cassava Crop in Vitória Da Conquista, State of Bahia, Brazil. Bioscience Journal, 29, 1130-1140.

[33] Maciel, C.D.G; Hama, J.T. and Souza, J.I. (2010) Desenvolvimento inicial de gramado semeado com Paspalum notatum Flügge. Pesquisa Agropecuária Tropical, 40, 547-549. https://doi.org/10.1590/S1983-40632010000400022

[34] Marques, L.J.P., Silva, M.R.M., Araújo, M.S., Lopes, G.S., Corrêa, M.J.P., Freitas, A.C.R. and Muniz, F.H. (2010) Composição florística de plantas daninhas na dultura do feijão-caupi no sistema de capoeira triturada. Planta Daninha, 28, 939-951. 
https://doi.org/10.1590/S0100-83582010000500003

[35] Kawakita, K., Rodrigues, R.S. and Filgueiras, T.S. (2016) Poaceae em uma planície de inundação no Brasil: listagem florística e novas ocorrências. Hoehnea, 43, 203-216. https://doi.org/10.1590/2236-8906-76/2015

[36] Moreira, H.J.D.C. and Bragança, H.B.N. (2010) Manual de identificação de plantas infestantes: arroz. FMC Agricultural Products, São Paulo, 854 p.

[37] Erasmo, E.A.L., Bianco, S. and Pitelli, R.A. (1997) Estudo sobre o crescimento de fedegoso. Planta Daninha, 15, 170-179.

https://doi.org/10.1590/S0100-83581997000200010 